\title{
TEXTILE INDUSTRY IN NORTH MACEDONIA
}

\author{
Silvana Zezova ${ }^{1 *}$, Sonja Jordeva ${ }^{1}$, Sashka Golomeova Longurova ${ }^{1}$, Aco Janevski' \\ 1 University "Goce Delchev", Shtip, Faculty of Technology, Štip, \\ Republic of North Macedonia \\ *e-mail: silvana.zezova@ugd.edu.mk \\ Professional paper \\ UDC: $677(497,7): 338.1$ \\ doi: $10.5937 /$ tekstind $2003044 Z$
}

\begin{abstract}
The textile industry in North Macedonia is one of the most important industry sectors with a long tradition and experience and plays an enormous part in the general economic performance and external position of the country. According to the latest structural data, the textile and garment industry in 2019 recruits around 35,000 workers, or $27 \%$ of the total number of employees in the manufacturing sector, dealing with the industry. The textile sector participates with 13\% in the industry's GDP and represents 10\% of the total exports in average. The purpose of this paper is to explore the development of the textile industry in the Republic of North Macedonia in the last 10 years.
\end{abstract}

Keywords: textile production, wearing apparel, net wage, Industrial production volume indices

\section{TEKSTILNA INDUSTRIJA U SEVERNOJ MAKEDONIJI}

Apstract: Tekstilna industrija u Severnoj Makedoniji jedan je od najvažnijih industrijskih sektora sa dugom tradicijom i iskustvom i igra veoma veliku ulogu u ukupnom ekonomskom učinku i spoljnoj poziciji zemlje. Prema poslednjim relevantnim podacima, tekstilna i odevna industrija u 2019. godini zapošljavaju oko 35.000 radnika, odnosno 27\% ukupnog broja zaposlenih u industrijskom proizvodnom sektoru. Tekstilni sektor učestvuje sa 13\% u industrijskom BDP-u i predstavlja 10\% ukupnog izvoza u proseku. Svrha ovog rada je istražiti razvoj tekstilne industrije u Republici Severnoj Makedoniji u poslednjih 10 godina.

Klučne reči: tekstilna proizvodnja, odeća, neto plate, indeksi obima industrijske proizvodnje.

\section{INTRODUCTION}

The textile industry in North Macedonia is one of the most important industry sectors with a long tradition and experience and plays an enormous part in the Macedonian economy [1, 2]. According to the national Classification of Activity (NCA), textile companies in North Macedonian are divided into two groups [3]:
1. manufacturers of textile materials;

2. manufacturers of wearing apparel, dressing and dyeing of fur.

According to the NACE Rev.21 classification in 2017 year, a total of 1076 companies were registered, 875 companies were registered in the clothing manufacturing segment and 201 in the production of textiles, as it is shown in the Table 1. 
Table 1: Number of companies in the Textile and Garment Industry (NACE Rev.2)

\begin{tabular}{|c|c|c|c|c|c|c|c|}
\hline Classification & 2011 & 2012 & 2013 & 2014 & 2015 & 2016 & 2017 \\
\hline B 13. - Manufacture of textiles & 202 & 203 & 192 & 200 & 193 & 195 & 201 \\
\hline B 13.1 - Preparation and spinning of textile fibres & 9 & 9 & 6 & 5 & 6 & 8 & 6 \\
\hline B 13.2 - Weaving of textiles & 10 & 9 & 9 & 11 & 8 & 11 & 9 \\
\hline B 13.3 - Finishing of textiles & 51 & 52 & 46 & 46 & 52 & 46 & 47 \\
\hline B 13.9- Manufacture of other textiles & 132 & 133 & 131 & 138 & 127 & 130 & 139 \\
\hline B 13.91 - Manufacture of knitted and crocheted fabrics & 5 & 3 & 2 & 2 & 2 & 2 & 4 \\
\hline $\begin{array}{l}\text { B } 13.92 \text { - Manufacture of made-up textile articles, } \\
\text { except apparel }\end{array}$ & 72 & 73 & 74 & 75 & 76 & 75 & 78 \\
\hline B 13.93 - Manufacture of carpets and rugs & 5 & 5 & 5 & 4 & 2 & 1 & / \\
\hline $\begin{array}{l}\text { B } 13.94 \text { - Manufacture of cordage, rope, twine and } \\
\text { netting }\end{array}$ & 4 & 5 & 5 & 6 & 5 & 5 & 4 \\
\hline $\begin{array}{l}\text { B } 13.95 \text { - Manufacture of non-woven and articles } \\
\text { made from non-woven, except apparel }\end{array}$ & 4 & 4 & 3 & 2 & 1 & 2 & / \\
\hline $\begin{array}{l}\text { B } 13.96 \text { - Manufacture of other technical and } \\
\text { industrial textiles }\end{array}$ & 1 & 2 & 1 & 1 & 1 & 3 & / \\
\hline B 13.99 - Manufacture of other textiles n.e.c. & 41 & 41 & 41 & 48 & 40 & 42 & 47 \\
\hline B14 - Manufacture of wearing apparel & 968 & 943 & 916 & 878 & 894 & 916 & 875 \\
\hline $\begin{array}{l}\text { B14. } 1 \text { Manufacture of wearing apparel, except fur } \\
\text { apparel }\end{array}$ & 920 & 900 & 877 & 839 & 857 & 877 & 839 \\
\hline B14.11 - Manufacture of leather clothes & 7 & 7 & 7 & 6 & 4 & 5 & 4 \\
\hline B14.12 - Manufacture of workwear & 74 & 72 & 70 & 69 & 70 & 72 & 71 \\
\hline B14.13 - Manufacture of other outerwear & 754 & 739 & 716 & 684 & 704 & 719 & 692 \\
\hline B14.14 - Manufacture of underwear & 48 & 50 & 54 & 51 & 48 & 53 & 49 \\
\hline $\begin{array}{l}\text { B14.19 - Manufacture of other wearing apparel and } \\
\text { accessories }\end{array}$ & 37 & 32 & 30 & 29 & 31 & 28 & 23 \\
\hline B14.2 - Manufacture of articles of fur & 4 & 4 & 3 & 3 & 4 & 4 & 4 \\
\hline B14.3 - Manufacture of knitted and crocheted apparel & 44 & 39 & 36 & 36 & 33 & 35 & 32 \\
\hline B14.31- Manufacture of knitted and crocheted hosiery & 24 & 23 & 21 & 19 & 19 & 18 & 16 \\
\hline $\begin{array}{l}\text { B14.39- Manufacture of other knitted and crocheted } \\
\text { apparel }\end{array}$ & 20 & 16 & 15 & 17 & 14 & 17 & 16 \\
\hline
\end{tabular}

Source: State Statistical Office, The Republic of North Macedonia (MAKSTAT Database) [4]

According to the latest structural data, in the clothing manufacturing sector around 500 companies are active and recruit around 27.000 employees in total. According to the number of employees, $50 \%$ are small enterprises recruiting between 10 and 49 workers, $35 \%$ are medium size enterprises who recruit between 50 and 249 workers and only $5 \%$ are large company with more than 250 employees (Table 2). 
Table 2: Number of enterprises in the Textile and Garment Industry

\begin{tabular}{|c|c|c|}
\hline Type of enterprises & Number of employees & Total number of enterprises \\
\hline Micro enterprises & $<10$ & 60 \\
\hline Small enterprises & $10-49$ & 253 \\
\hline Medium - sized enterprises & $50-249$ & 170 \\
\hline Large enterprises & $>250$ & 24 \\
\hline
\end{tabular}

Source: State Statistical Office, The Republic of North Macedonia (MAKSTAT Database) [4]

Textile industry is covering the entire territory of the Republic of North Macedonia and there are 8 large regions regarding the spatial concentration of textile companies throughout the country (Table 3 ). More than a $40 \%$ (209 active companies) of the total textile companies are placed in the Eastern Statistical region. $14 \%$ or 65 companies are located in Southeastern region, followed by Skopje planning region with $11 \%$ (56 active companies), the Pelagonia region with $5 \%$
(43 companies), the Vardar region with 32 companies the Southwest region with 26 companies, the Northeast region with 21 companies and the Polog region with 15 active companies [5].

The center of the textile and garment industry is the town of Shtip, with 77 apparel companies, followed by Kocani with more than 50 companies, and Delcevo with about 30 companies (table 3 ).

Table 3: Number of textile and apparel companies per city [5]

\begin{tabular}{|c|c|c|c|}
\hline City & Number of companies & City & Number of companies \\
\hline \multicolumn{2}{|c|}{ EAST REGION (209) } & \multicolumn{2}{|c|}{ VARDAR REGION (32) } \\
\hline Shtip & 77 & Veles & 9 \\
\hline Kocani & 53 & Kavadarci & 9 \\
\hline Vinica & 22 & Sveti Nikole & 7 \\
\hline Probishtip & 8 & Negotino & 7 \\
\hline Delchevo & 31 & \multicolumn{2}{|c|}{ SKOPJE REGION (56) } \\
\hline Berovo & 6 & Skopje & 56 \\
\hline Makedonska Kamenica & 7 & \multicolumn{2}{|c|}{ PELAGONIA REGION (43) } \\
\hline Zrnovci & 5 & Prilep & 25 \\
\hline \multicolumn{2}{|c|}{ SOUTHEAST REGION (65) } & Bitola & 18 \\
\hline Radovish & 13 & \multicolumn{2}{|c|}{ SOUTHWEST REGION (26) } \\
\hline Strumica & 22 & Ohrid & 17 \\
\hline Gevgelija & 21 & Struga & 9 \\
\hline Valandovo & 9 & & \\
\hline \multicolumn{2}{|c|}{ NORTHEAST REGION ( 21) } & \multicolumn{2}{|c|}{ POLOG REGION (15) } \\
\hline Kumanovo & 15 & Tetovo & 15 \\
\hline Kratovo & 6 & & \\
\hline
\end{tabular}

Source: Textile Trade Association -Textile Cluster 


\section{NUMBER OF EMPLOYEES}

According to the structural data shown in table 4 the textile and garment industry in 2019 employs around 35,000 workers, or $27 \%$ of the total number of employees in the manufacturing sector, dealing with the industry. Over the entire period between 2011 and 2018, approximately $7 \%$ of the total number of employees in the country were engaged in the textile and clothing industry.

In the past 9 years the number of employees in the apparel industry is reduced for near 8000 workers or $23 \%$. On the other hand, in the sector for manufacture of textile there is an increase in the number of employees, from 3,714 employees in 2010 to 7,316 in 2019 , i.e. an increase of 3602 employees [6].
Today, the situation in the textile industry is even more difficult due to the crisis imposed by the corona virus, which has contributed to the reduction in the number of employees in the textile and clothing industry.

The salaries of textile employees are perhaps the most problematic issues of this industry. In table 5 is presented the average net wage per employee within the period from 2010 to 2019 . The data show that for the period from 2010 to 2019 the average net wage in both sectors have been growing continuously. The average net wage in the textile sector are higher than net wage in the clothing industry. The average net wage in the clothing industry is around 270 EUR, which puts the garment industry among the least paid industries in the country [7].

Table 4: Number of employees in the textile industry, 2010-2019

\begin{tabular}{|c|c|c|c|c|c|}
\hline \multirow[b]{2}{*}{ Year } & \multicolumn{4}{|c|}{ SECTOR } & \multirow[b]{2}{*}{$\begin{array}{c}\text { Total of } \\
\text { employees in } \\
\text { textile sector }\end{array}$} \\
\hline & $\begin{array}{c}\text { Total number } \\
\text { of employees in } \\
\text { North Macedonia }\end{array}$ & $\begin{array}{l}\text { Total number } \\
\text { of employees in } \\
\text { manufacturing }\end{array}$ & $\begin{array}{c}\text { Manufacture of } \\
\text { textiles }\end{array}$ & $\begin{array}{l}\text { Manufacture of } \\
\text { wearing apparel }\end{array}$ & \\
\hline 2010 & 435078 & 101093 & 3714 & 34680 & 38394 \\
\hline 2011 & 458873 & 100878 & 3158 & 32525 & 35683 \\
\hline 2012 & 474398 & 101132 & 2717 & 33360 & 36077 \\
\hline 2013 & 483447 & 104214 & 2737 & 32611 & 35348 \\
\hline 2014 & 501788 & 111559 & 4928 & 32913 & 37841 \\
\hline 2015 & 519031 & 111208 & 5135 & 31742 & 36877 \\
\hline 2016 & 534200 & 111402 & 5286 & 30919 & 36205 \\
\hline 2017 & 548681 & 115614 & 6027 & 30243 & 36270 \\
\hline 2018 & 567230 & 124359 & 7519 & 28232 & 35751 \\
\hline 2019 & 619663 & 127831 & 7316 & 26920 & 34236 \\
\hline
\end{tabular}

Source: State Statistical Office, The Republic of North Macedonia [4]

Table 5: Average net wage paid per employee, 2010-2019

\begin{tabular}{|c|c|c|c|c|}
\hline & \multicolumn{4}{|c|}{ Net wage paid per employee } \\
\hline Year & Total & Total manufacturing & $\begin{array}{c}\text { Manufacture of } \\
\text { textiles }\end{array}$ & $\begin{array}{c}\text { Manufacture of } \\
\text { wearing apparel }\end{array}$ \\
\hline 2010 & 20553 & 14674 & 9746 & 9728 \\
\hline 2011 & 20847 & 15176 & 9623 & 10411 \\
\hline 2012 & 20902 & 15300 & 10059 & 10440 \\
\hline 2013 & 21145 & 15747 & 11067 & 10831 \\
\hline 2014 & 21394 & 16177 & 12662 & 11442 \\
\hline 2015 & 21906 & 16594 & 14107 & 12113 \\
\hline 2016 & 22342 & 17096 & 15435 & 12641 \\
\hline 2017 & 22928 & 18112 & 17949 & 13795 \\
\hline 2018 & 24276 & 20073 & 19767 & 15421 \\
\hline 2019 & 25213 & 21146 & 21129 & 191 \\
\hline
\end{tabular}

Source: State Statistical Office, The Republic of North Macedonia [4] 


\section{INDUSTRIAL PRODUCTION}

The textile industry is one of the leading manufacturing industries in North Macedonia with significant participation in GDP formation. The textile sector participates with 13\% in the industry's GDP. In table 6 are presented industrial production volume indices in textile industry for the past nine year. The data show that from 2016 to 2019, the manufacturing industry and the production of textiles have been growing continuously. $O$ the other hand, the clothing industry registered a decline in industrial production. Industrial production in the garment industry in 2019 decreased by $26 \%$ compared to $2016[8,9]$.

In table 7 are presented industrial production volume indices in textile industry for the last 5 mounts of 2020 compared to the same period in 2019 year. Since March 2020, the indices of industrial production in the textile and clothing industry have been steadily declining.

Table 6: Industrial production volume indices in textile industry, 2010-2019

\begin{tabular}{|c|c|c|c|c|}
\hline & \multicolumn{3}{|c|}{ Industrial production volume indices } \\
\hline Year & Total & Manufacturing & Manufacture of textiles & $\begin{array}{c}\text { Manufacture of wearing } \\
\text { apparel }\end{array}$ \\
\hline 2010 & 100 & 99 & 68 & 63 \\
\hline 2011 & 104 & 104 & 50 & 75 \\
\hline 2012 & 97 & 97 & 54 & 118 \\
\hline 2013 & 107 & 110 & 161 & 123 \\
\hline 2014 & 112 & 120 & 171 & 131 \\
\hline 2015 & 118 & 127 & 111 & 93 \\
\hline 2016 & 103 & 105 & 113 & 78 \\
\hline 2017 & 104 & 105 & 124 & 75 \\
\hline 2018 & 109 & 112 & 133,5 & 69 \\
\hline 2019 & 113 & 114 & & \\
\hline
\end{tabular}

Source: State Statistical Office, The Republic of North Macedonia, (MAKSTAT Database) [4]

Table 7: Industrial production volume indices

in textile industry 2020 (M01-05) vs 2019 (M01-05)

\begin{tabular}{|c|c|c|c|c|c|c|c|c|}
\hline & \multicolumn{9}{|c|}{ Industrial production volume indices } \\
\hline & \multicolumn{2}{|c|}{ Total } & \multicolumn{2}{c|}{ Manufacturing } & \multicolumn{2}{c|}{$\begin{array}{c}\text { Manufacture of } \\
\text { textiles }\end{array}$} & \multicolumn{2}{c|}{$\begin{array}{c}\text { Manufacture of wearing } \\
\text { apparel }\end{array}$} \\
\hline Year & 2019 & 2020 & 2019 & 2020 & 2019 & 2020 & 2019 & 2020 \\
\hline January & 99,5 & 99,8 & 90,0 & 94,1 & 115,5 & 137,7 & 64,7 & 68,7 \\
\hline February & 104,4 & 108,0 & 102,6 & 109,3 & 132,5 & 148,3 & 72,3 & 79,1 \\
\hline March & 117,5 & 101,7 & 119,4 & 102,3 & 144,3 & 121,9 & 73,2 & 61,6 \\
\hline April & 107,6 & 71,6 & 111,1 & 66,0 & 139,4 & 52,3 & 73,4 & 40,5 \\
\hline May & 112,4 & 82,1 & 118,1 & 80,1 & 144,1 & 79,3 & 72,2 & 46,3 \\
\hline
\end{tabular}

Source: State Statistical Office, The Republic of North Macedonia, (MAKSTAT Database) [4]] 


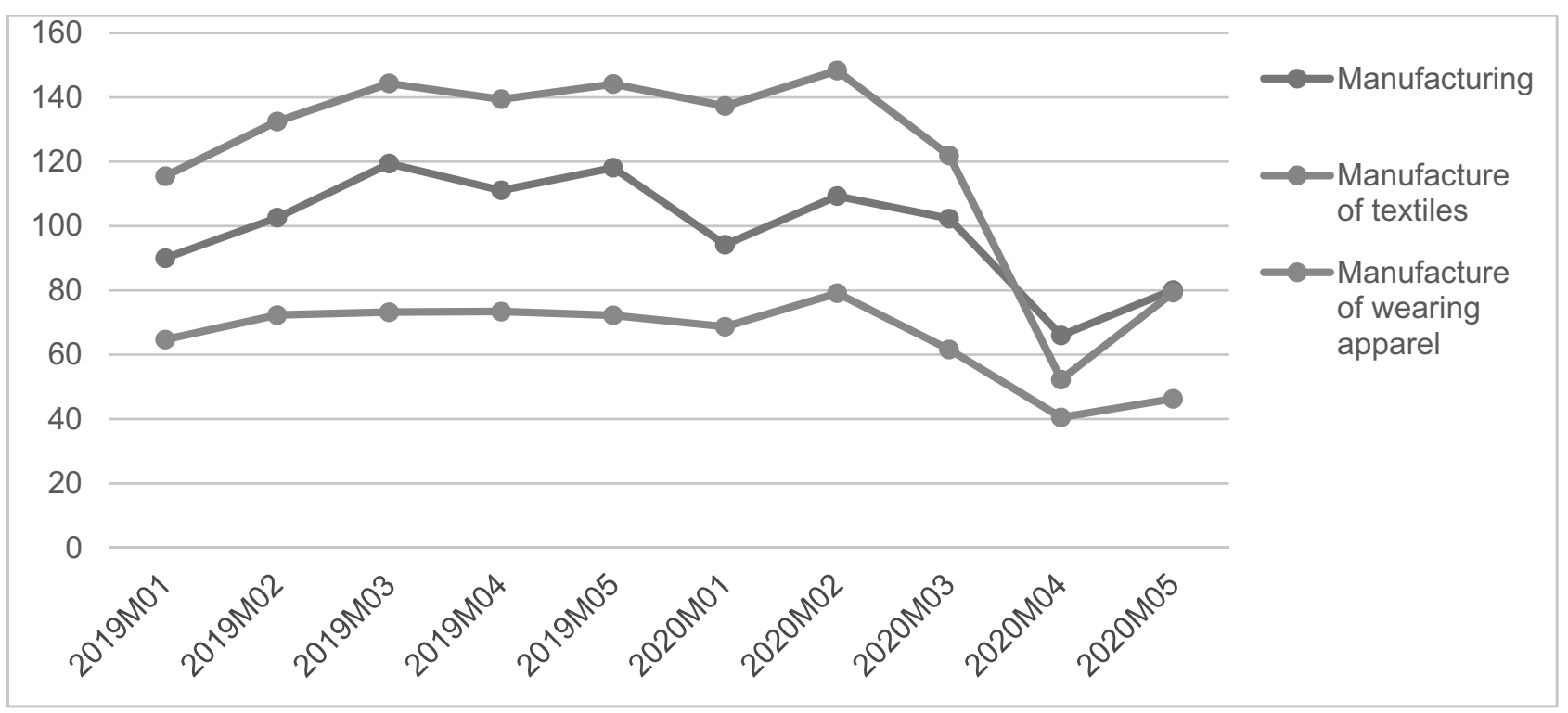

Figure 1: Industrial production volume indices in textile industry, January-May 2019, January-May 2020

According to the data on industrial production (Figure 1), in May 2020 the production of textile has reduced by $45 \%$, while the production of clothing has decreased by $35 \%$ compared to the same period in 2019. Predictions are that the downfall of these sectors however, will continue in the next months as a result of the crises caused by Covid 19.

\section{EXPORT AND IMPORT OF TEXTILE}

Apparel and textile production in The Republic of North Macedonia is an important export-oriented sector. About $93 \%$ of apparel manufacturing companies in The Republic of North Macedonia are oriented towards export (CM и CMT arrangement). This brings small profits even though the companies manufacture for a large number of well-known worldwide brands: Italy (Massimo Rebecchi, Versace, Diesel, Gucci, Nanette, Cinque, Pinko, MaxMara, Vestebene), Germany (Marc Cain, Steilman, Gerry Weber, Apanage, Wahler, Betty Barclay, Escada, Zommermann, A\&R Quindici Rabe, Elite Moden, Franken Waelder, Marc Aurel, Mode Institut), Austria (Jones), Netherlands (Barnett \& Barnett, La Salle ), Belgium (Ahlers, L\&V), Denmark (Bruns Bazaar, Bertoni, Samsoe\&Samsoe), Czech Republic (Opro CZ) etc. Only a small number of apparel companies have complete production (from obtaining raw materials through creating the final product - OEM). The reasons for this are many because the complete production process is a long and hard process which requires certain capacities, such as technological-technical, financial and human resources $[5,9,10]$.

Textile is traditionally one of the most widely used products in the export of the Republic of North
Macedonia. The most important export destinations for Macedonian textile products, with over $65 \%$ of total exports are: Germany, the Netherlands, Austria, Bulgaria, the United Kingdom, Switzerland, Greece, Italy and the Czech Republic. The mostly exported groups of products are: women's and girls' blouses, T-shirts, suits, vests, jackets and blazers. The table 8 shows the progress of the export and import of textiles in the period from 2010 until 2020. In the past six years, there has been a decline in the value of clothing export by $15 \%$ in 2019 compared to 2014.The presented data show that the annual import of garments from $2010-2019$ is continuously increasing and is usually imported from China, Greece, Turkey, Germany and Italy. Generally, the export of textiles is higher than the import, so the Republic of North Macedonia is a net exporter $[10,11]$.

\section{CONCLUSION}

The textile industry is one of the leading manufacturing industries in the Republic of North Macedonia with significant participation in GDP formation, high labor absorption and exports. About 1100 companies are registered in the textile industry, out of which 500 are active in the clothing manufacturing sector and recruit around 35.000 employees in total. The total number of employees in textile industry constantly decreases from year to year, i.e. from 38394 employees in 2010, the number of employees decreased to 34236 employees in 2019, 7316 of whom worked in the field of manufacture of textile and 26920 in the field of garment production. 
Table 8: Export and import of textile and wearing apparel, cumulative data, 2010-2020 (M01-M04)

\begin{tabular}{|c|c|c|c|c|c|c|c|}
\hline \multirow[b]{2}{*}{ Year } & \multicolumn{3}{|c|}{ Export/ Value in thousand EUR } & \multicolumn{3}{|c|}{ Import/Value in thousand EUR } & \multirow{2}{*}{$\begin{array}{c}\text { Difference } \\
\text { (export - } \\
\text { import) }\end{array}$} \\
\hline & Textile & $\begin{array}{c}\text { Wearing } \\
\text { apparel }\end{array}$ & Total & Textile & $\begin{array}{l}\text { Wearing } \\
\text { apparel }\end{array}$ & Total & \\
\hline 2010 & 47341 & 425888 & 473229 & 307951 & 45708 & 353659 & 119570 \\
\hline 2011 & 48782 & 473456 & 522238 & 344218 & 43625 & 387843 & 134395 \\
\hline 2012 & 54140 & 468542 & 522682 & 340014 & 46496 & 386510 & 136172 \\
\hline 2013 & 65976 & 471973 & 537949 & 358626 & 51327 & 409953 & 127996 \\
\hline 2014 & 68940 & 507546 & 576486 & 393269 & 57022 & 450291 & 126195 \\
\hline 2015 & 76946 & 480456 & 557402 & 410923 & 62695 & 473618 & 83784 \\
\hline 2016 & 90777 & 472415 & 563192 & 414069 & 72897 & 486966 & 76226 \\
\hline 2017 & 93755 & 462847 & 556602 & 436850 & 76400 & 513250 & 43352 \\
\hline 2018 & 106229 & 453215 & 559444 & 444772 & 83867 & 528639 & 30805 \\
\hline 2019 & 105904 & 430937 & 536841 & 433047 & 90816 & 523863 & 12978 \\
\hline 2020 (M01-04) & 39546 & 127658 & 167204 & 112272 & 22632 & 134904 & 32300 \\
\hline
\end{tabular}

Source: State Statistical Office, The Republic of North Macedonia, (MAKSTAT Database) [4]

The data show that from 2016 to 2019 , the manufacturing industry and the production of textiles have been growing continuously. On the other hand, the clothing industry registered a decline in industrial production in 2019 by $26 \%$ compared to 2016 . According to the data for the industrial production in the first five months of 2020, in January and February 2020, there was an increase in industrial production compared to the same periods in 2019, while in March there was a decline in industrial production by $15 \%$. Predictions are that the downfall of these sectors however, will continue in the next months as a result of the crises caused by Covid 19.

About $93 \%$ of the apparel production is organized according to the CM and CMT system for the foreign countries. This brings small profits even though the companies manufacture for a large number of wellknown worldwide brands. One of the main problems is the low competitive strength of the textile industry. The positive development of companies involved in this industry depends from restructuring of the production, investing in complete production facilities, investing in new technology and equipment (modernization of production), investing in intellectual capital to increase the quality and productivity, creation of domestic brands, investing into promotion on foreign markets for foreign clients. The potential and possibilities for complete production are huge but the main problem are the big investments in complete production companies.

\section{REFERENCES}

[1] Strategy for development of the textile industry in Republic of Macedonia, (June 2007) Ministry of Economy, Skopje.

[2] The history of the Macedonian textile industry with a focus of Shtip (2005), Occasional paper, No.8, Skopje.

[3] Textile Trade Association-Textile Cluster, (http:// macedoniantextiles.mk/index.php/directory-ofcompanies/browse-directory;)

[4] State Statistical Office, The Republic of North Macedonia, MakStat database,

http://www.stat.gov.mk/Default_en.aspx/ )

[5] Zhezhova, S., Janevski, A., Jodeva, S., Andronikov, D. and Mojsov, K. (2017) Apparel Industry in Macedonia, Conditions and Challenges. XII Simpozijum "Savremene tehnologije i privredni razvoj". p. 141147. 
[6] Macedonia in numbers (2018), State Statistical Office of the Republic of Macedonia.

[7] Average monthly gross salary per employee, April 2010-2017 State statistical office of Republic of Macedonia 2017, http://www.stat.gov.mk/ PrikaziSoopstenie.aspx?rbrtxt=41/)

[8] Veselinova, E., Milevski, G. (2018) Местото и значењето на текстилната индустрија во националната економија на Република Македонија: учество во БДП, извозот и вработеноста. Годишен зборник 15 (10).

[9] EconomicchamberofMacedonia,TextileandLeather Industry Association, (http://www.mchamber.mk/ Default.aspx?mld=12\&htmlid=747\&lng=2;
[10] Textile industry in North Macedonia (2019) SouthEast European Industrial Market - issue 1/2019, (https://www.see-industry.com/en/textileindustry-in-north-macedonia/2/1816/

[11] Macedonia: A new land of opportunities, (July 2005), Fibre2Fashion,

https://www.fibre2fashion.com/industryarticle/7599/macedonia-a-new-land-ofopportunities.

Rad primljen: 25.07.2020.

Rad prihvaćen: 28.09.2020. 